\title{
The Black-necked Cranes Grus nigricollis of Ruoergai Marshes, Sichuan, China
}

\author{
D. A. SCOTT
}

\begin{abstract}
Summary
The marshes of the Hongyuan-Ruoergai Plateau in northern Sichuan were visited between 27 May and 1o June 1991 to determine the status there of Black-necked Cranes Grus nigricollis, to investigate reports of threats to their habitat from peat-mining, and to consider options for a protected area for the cranes. Almost 80,000 ha of wetlands in Ruoergai County were surveyed, as well as some of the contiguous wetlands in northern Hongyuan County; 240 Black-necked Cranes and 24 active nests were located. Between 600 and 900 cranes were estimated to be present on the plateau, making this the most important breeding and summering area for the species hitherto known. Neither peatmining nor hunting was judged to pose a threat to the cranes. The principal threat is drainage of habitat for pastureland: overgrazing by domestic livestock is a serious problem on the grasslands, and some drainage of bogs has already occurred in an attempt to increase the area of grazing land. The establishment of a large "crane conservation area" has been proposed, in which there would be no restrictions on the traditional activities of the local tribespeople, but where large-scale drainage, peat-mining and other development activities likely to have a negative impact on the wetlands would be prohibited.
\end{abstract}

\section{Introduction}

In May 1991, I was invited by the World Wide Fund for Nature (WWF) to participate in a joint expedition with the Sichuan Forestry Department to survey the extensive Ruoergai Marshes on the edge of the Tibetan Plateau in northern Sichuan (Szechwan) Province, China. The main objectives of the expedition were to determine the importance of the wetlands for the threatened Blacknecked Crane Grus nigricollis, to assess the impact of peat-mining activities on crane habitat, and to investigate the feasibility of establishing a nature reserve for the cranes.

Ruoergai Marshes, on the Hongyuan-Ruoergai Plateau, have long been known to be a breeding area for Black-necked Cranes, and were identified as a wetland of international importance in Scott (1989). The creation of a nature reserve for the cranes was first suggested in the early 1980s, but little progress was made until 1990, when the Chinese Ministry of Forestry raised the matter with WWF and suggested that a survey be undertaken to investigate the feasibility of establishing a reserve in the marshes. At about the same time, the International Crane Foundation (ICF) and Asian Wetland Bureau were receiving reports from Sichuan which suggested that the wetlands were under threat from a peat-mining operation near Hongyuan town (Anon. 1990). Following a series 
of discussions between the Chinese Ministry of Forestry, Sichuan Forestry Department and WWF in late 1990, it was agreed that a joint expedition by these two bodies should be made to the marshes during the crane breeding season in 1991.

The expedition, which included myself, my wife, two biologists from the Sichuan Forestry Department and a driver, left Chengdu (Chengtu), the capital of Sichuan, on 25 May and, after two days of driving, arrived at the small town of Ruoergai on the high plains of the Hongyuan-Ruoergai Plateau. Accompanied by a local Tibetan guide from the Forestry Bureau in Ruoergai, the expedition spent the next 15 days (27 May to 10 June) exploring the wetlands and rolling grasslands of Ruoergai County and neighbouring areas of northern Hongyuan County. A full report of the expedition, along with a number of recommendations for the conservation of the Black-necked Cranes and their wetland habitat, has been submitted to WWF (Scott 1991).

Most of the fieldwork was carried out in the marshes of Ruoergai County, and special attention was given to the area of the proposed nature reserve near the village of Xiamen. An attempt was made to visit all those parts of the marshes accessible by vehicle, and also to hike into all those areas where Blacknecked Cranes had been observed by personnel of the Sichuan Forestry Department during surveys in the early 1980 s.

Excellent 1:100,0oo topographic maps were available for the whole of the area under investigation. Although produced in the 1960s, these maps were found to be remarkably accurate with respect to the extent of the marshes and peat bogs, indicating that very little wetland had been lost to drainage in the past 25 years. Furthermore, the maps made a clear distinction between deep, permanent marshes, too wet for domestic livestock, and shallow marshes accessible to livestock. It soon became apparent that crane densities were highest in the former, and this enabled the expedition to focus its attention on areas marked as such on the maps.

During most of the survey, visibility was excellent, with only minor problems from heat haze, and this allowed extensive use of telescopes. It was found that under normal conditions cranes were readily visible through a $\times 30$ telescope at ranges of up to six or seven kilometres. Most marshes could be surveyed from vantage points on adjacent hills, and thus it was possible to cover large areas of marsh in a relatively short period of time.

After 12 days in the Ruoergai Marshes, the expedition moved to Hongyuan County and spent three days investigating the extensive marshes in the north of that county before returning to Chengdu.

\section{Ruoergai Marshes, the study area}

The Hongyuan-Ruoergai Plateau $\left(33^{\circ} 30^{\prime}-34^{\circ} \mathrm{Oo} 0^{\prime} \mathrm{N} 102^{\circ} 10^{\prime}-102^{\circ} 55^{\prime} \mathrm{E}\right)$ is situated in the headwaters of the Huang Ho (Yellow River) on the south-eastern edge of the Tibetan Plateau. Elevations range from about 3,400 to $3,900 \mathrm{~m}$, with the surrounding snow-capped mountain ranges rising to peaks at about $4,500 \mathrm{~m}$. The marshes comprise some 300,000 ha of peat-bogs, sedge marshes, lakes and marshy grasslands in the lower basins of the Heihe and Baihe rivers in Ruoergai County, northern Hongyuan County and eastern Maqu County (in neigh- 
bouring Gansu Province). The principal marshes lie at 3,400 to 3,460 $\mathrm{m}$ above sea level along tributary streams of the two main rivers, and extend from the Wa Chie to Songpan road in the south to the confluence of the Heihe and Baihe rivers in the north-west (see Figure 1). Much the most important marshes (some 270,000 ha) lie in Ruoergai County.

The name "Hongyuan-Ruoergai Plateau" is somewhat misleading as the region is traversed by numerous hill ranges rising $300-400$ metres above the level of the plains. Thus, Ruoergai Marshes are not a single vast wetland ecosystem, but rather a large number of relatively discrete wetlands in poorly drained valleys separated by hill ranges. Large parts of the extensive plains in the northwest and in the two main river valleys are well drained and rather dry. The alluvial soils are sandy (there are sand-dunes in some areas), and the only permanent wetlands in these areas are small oxbow lakes in abandoned river channels. The rivers flow in deep channels with extensive sandbanks and, in some places, high cliffs. Large areas of the plains support terrestrial plant communities, primarily grasses, and are heavily grazed by domestic animals, mainly sheep, yak and horses. Many of the peat-bogs, particularly those on hillsides and in the more steeply sloping side valleys, are sufficiently firm to support grazing livestock, but the deeper sedge marshes in broad depressions between hill ranges are too wet for anything except horses.

The southern edge of the main wetland area near Wa Chie lies about $40 \mathrm{~km}$ north-east of Hongyuan town. Many smaller wetlands, principally peat-bogs, occur further south in Hongyuan County, especially in side valleys of the Baihe river near Hongyuan town, but few of these exceed 1, ooo ha in extent. Other wetlands occur in the Long $\mathrm{Zi} \mathrm{Ba}$ area, over $50 \mathrm{~km}$ south of Hongyuan, and one of these, $4 \mathrm{~km}$ south of Long $\mathrm{Zi} \mathrm{Ba}$, is sufficiently large and undisturbed to support a pair of Black-necked Cranes.

The Hongyuan-Ruoergai Plateau is inhabited by tribal people of Tibetan origin, almost exclusively pastoralists with vast herds of sheep, yak, horses, cattle and goats. The people live a seminomadic life, camping out on the plains during the summer months and retreating to permanent villages along the edge of the hills for the winter. Although the human population remains relatively small, the number of livestock is immense. Bjork and Digerfeldt (1990) gave a total of 420,900 yak, sheep and horses in Hongyuan County in 1989, while the figure for Ruoergai County is believed to exceed one million.

The region remains rich in wildlife, especially waterbirds, and supports a diverse Tibetan/Himalayan flora. The most conspicuous breeding waterbirds in 1991 were Great Crested Grebe Podiceps cristatus, Greylag Goose Anser anser, Ruddy Shelduck Tadorna tadorna, Mallard Anas platyrhynchos, Ferruginous Duck Aythya nyroca (over 150 individuals recorded), Moorhen Gallinula chloropus, Coot Fulica atra, Redshank Tringa totanus and Common Tern Sterna hirundo. Brownheaded Gulls Larus brunnicephalus were fairly common around lakes and in the wetter marshes, and were thought to be breeding locally, although no colonies were located. Common birds of the grasslands included Common Cuckoo Cuculus canorus, Little Owl Athene noctua, Long-billed Calandra Lark Melanocorypha maxima, Oriental Skylark Alauda gulgula, Horned Lark Eremophila alpestris, Sand Martin Riparia riparia, Citrine Wagtail Motacilla citreola, Blyth's Pipit Anthus godlewskii, Rosy Pipit A. roseatus, Hume's Ground Jay Pseudopodoces humilis, Raven 


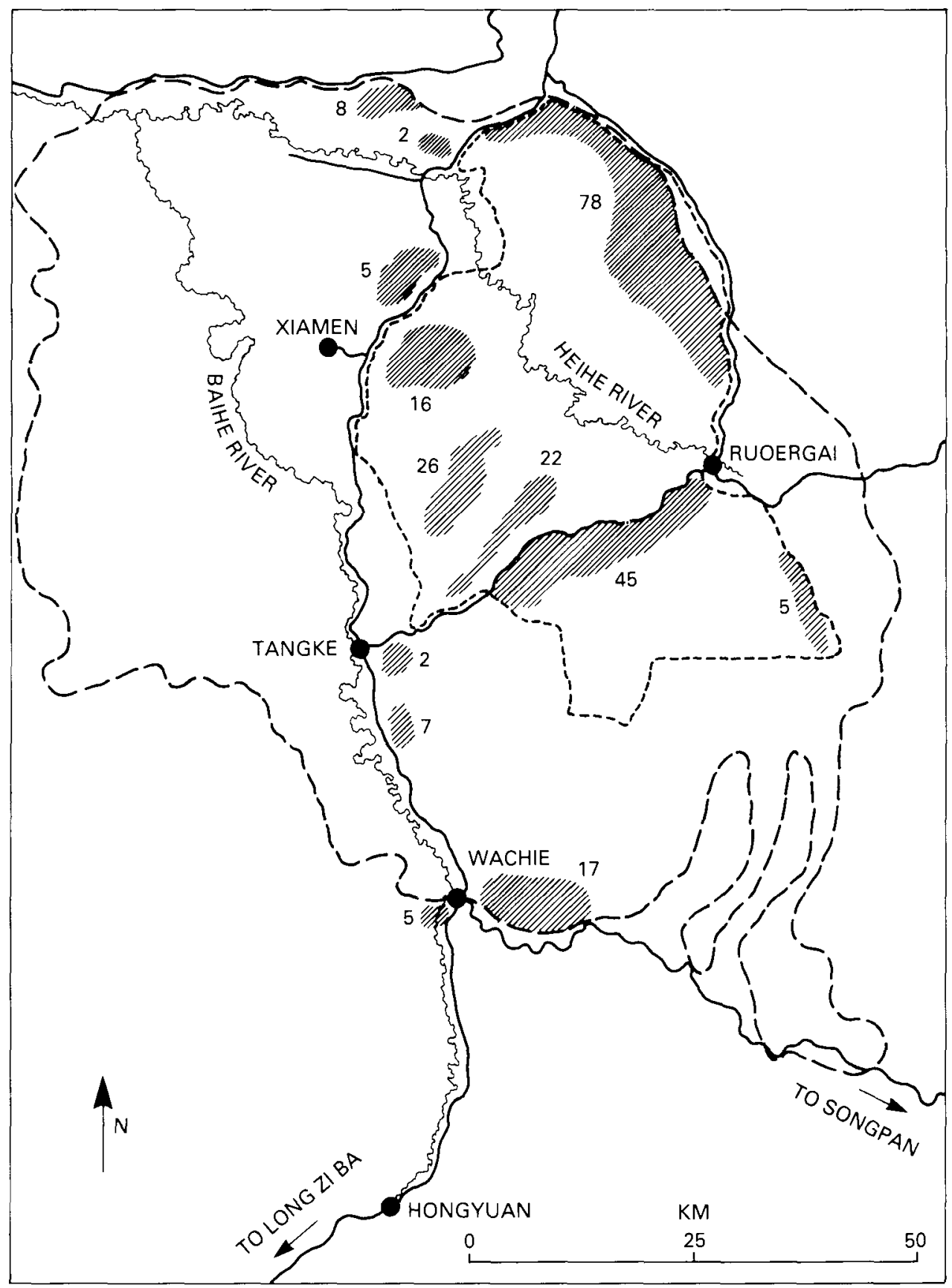

Figure 1. The marshes of the Hongyuan-Ruoergai Plateau, Sichuan, China, and distribution of Black-necked Crane sightings, May/June 1991. Key: continuous line, main roads; long dashes, limit of principal wetlands; short dashes, proposed boundaries for Crane Conservation Area; shaded areas, distribution of crane sightings, with number of individuals in each area (the Long $\mathrm{Zi} \mathrm{Ba}$ area, with two cranes, is off the map to the south). 
Corous corax, Black Redstart Phoenicurus ochruros, Stonechat Saxicola torquata, Tree Sparrow Passer montanus, Tibetan Snowfinch Montifringilla adamsi, Twite Acanthis flavirostris and Rock Bunting Emberiza cia. Black Kite Milvus migrans, Himalayan Griffon Vulture Gyps himalayensis and Upland Buzzard Buteo hemilasius were fairly common and widespread, and Lammergeier Gypaetus barbatus, Cinereous Vulture Aegypius monachus and Saker Falcon Falco cherrug were each recorded on several occasions. Other interesting birds observed during the survey included three separate immature Black Storks Ciconia nigra, an immature Common Crane Grus grus with a small party of immature Black-necked Cranes, and a male Isabelline Wheatear Oenanthe isabellina in song and apparently on territory.

Rather few species of mammal were recorded during the survey. The Himalayan marmot Marmota himalayana was common on open grassy hillsides throughout, and Tibetan gazelles Procapra picticaudata were recorded on six occasions (a total of 16 individuals). Wolves Canis lupus appeared to be fairly common: the species was observed on four occasions, including a pack of five adults east of Xiamen and a pack of four adults with a small cub in a peat-bog $35 \mathrm{~km}$ west of Ruoergai. Other mammals encountered during the survey included a pika Ochotona sp., common hare Lepus capensis, red fox Vulpes vulpes, common badger Meles meles and roe deer Capreolus capreolus. No wild ass Equus hemionus was observed; the species was said to have been fairly cornmon on the plains, but was heavily persecuted in the late 1950s and early 1960s and was now thought to be close to extinction in the area.

At the time of the survey, the spring flowering season was at its peak, and vast areas of peat-bog and marsh were carpeted with flowers, mostly marsh marigolds Caltha scaposa. Other dominant plants of the marshes and damp grassland included Carex sp., Kobresia humilis, Deschampsia caespitosa, Sanguisorba filiformis, Triglochin maritimum, Ranunculus tanguticus, Trollius farreri, Lancea tibetica, Cremanthodium lineare and Polygonum viviparum. The many small lakes and ponds supported a rather impoverished aquatic flora dominated by Cremanthodium lineare, C. platagineum, Chamaesium paradoxum, Batrachium sp. and Potamogeton viviparum (Sichuan Forestry Department in litt.).

\section{The Black-necked Cranes}

Black-necked Cranes have been known to breed in the marshes of north-western Sichuan since the 1930s (Archibaid and Oesting 1981), but it was not until the early 1980 s that any systematic attempt was made to survey the main breeding areas. Zhang !iaju and Xiong Tieyi of the Sichuan Provincial Natural Resources Research Institute conducted an investigation of the waterbirds of the Hongyuan-Ruoergai Plateau between 1982 and 1984, and concluded that there were about 100 cranes in the area. They thought that their number was decreasing because of drainage of bogs for pastureland, and that the cranes were being pushed back into the deeper swamps which were less accessible to the tribespeople and their livestock (Xiong Tieyi, pers. comm.). The total numbers of cranes observed during this first investigation are given in Table $I$.

During a brief visit to Ruoergai Marshes in May 1988, a British bird tour (Birdquest) observed between 60 and 70 cranes and located one nest (M. Beaman 
Table 1. Counts of Black-necked Cranes on the Hongyuan-Ruoergai Plateau, Sichuan, China, in $1982-1984$

\begin{tabular}{ccccc}
\hline & Ruoergai Co. & Hongyuan Co. & Maqu Co. & Total \\
\hline 1982 & 26 & - & - & 26 \\
1983 & 21 & 17 & 12 & 50 \\
1984 & 50 & - & - & 50 \\
\hline
\end{tabular}

Source: Sichuan Provincial Natural Resources Research Institute

pers. comm.). Similarly, an American bird tour (Kingbird Tours) located 68 cranes in the Ruoergai area during a two-day visit in May 1989, and 25 cranes in the same area in May 1990 (B. King pers, comm.). These high counts suggested that the region might support far more cranes than Zhang and Xiong had supposed.

No less than 240 Black-necked Cranes were observed during the present survey; 216 in Ruoergai County and 24 in Hongyuan County. Details of all crane observations are given in Table 2 , and the distribution of the sightings is shown in Figure 1.

The 240 cranes consisted of the following: 23 pairs at nests; one single bird at a nest; 56 apparently mated pairs feeding or resting; 24 single birds feeding or resting; and 57 first-year birds, mostly in small parties (maximum group size 12). Most of the 24 single birds were seen at great distance, and were thought to be off-duty birds of nesting pairs, the incubating birds being invisible at that range. The status of the 56 feeding or resting pairs was unclear. Archibald and Oesting (1981) report that in south-central Tibet and Sichuan eggs are laid from late May to mid-June, while in south-western Tibet and eastern Ladakh nesting begins even later, in mid-June, and continues into July. No small chicks were observed during the survey, and the behaviour of pairs at change-over on the nest (observed many times) indicated that the nests contained eggs rather than small chicks. Thus it seems very unlikely that any of the 56 pairs had already hatched their eggs. On the other hand, it seems likely that some were mated pairs which had not yet laid eggs, especially during the early part of the survey in late May. A few pairs may have been breeding birds which had lost their clutches, while others were probably subadult birds which were paired but had not yet reached breeding age.

No information seems to be available on the age of first breeding in the Black-necked Crane. However, from a comparison with other closely related cranes, it would seem likely to be at three to five years of age. Johnsgard (1983) stated that the age of first maturity in the Common Crane probably normally occurs at five years, but possibly at four and perhaps as late as six. Both sexes of the Sandhill Crane Grus canadensis are believed to start breeding in the wild at four years of age, while maturity in the Red-crowned Crane G. japonensis is thought to occur at three or four years of age (Johnsgard 1983). Thus many of the 56 pairs of uncertain status were probably subadult birds in their second, third or even fourth summers, which had not yet started to breed. Such birds would appear to be indistinguishable from breeding adults under normal field conditions. The possibility that some of the 56 pairs were adults of breeding age which had been unable to find a suitable nesting territory seems unlikely, 
Table 2. Summary of Black-necked Crane observations in Ruoergai and Hongyuan Counties, Sichuan, China: 26 May to 10 June 1991

\begin{tabular}{|c|c|c|}
\hline Location & Habitat & Crane observations \\
\hline \multicolumn{3}{|l|}{ Ruoergai County } \\
\hline $\begin{array}{l}\text { Valley } 4-25 \mathrm{~km} \text { SSE of } \\
\text { Ruoergai }\end{array}$ & $\begin{array}{l}\text { Wide marshy valley } \\
\text { with peat-bogs and } \\
\text { sedge marshes }\end{array}$ & $\begin{array}{l}\text { Pair at nest } \\
\text { Single feeding } \\
\text { Single feeding } \\
\text { One immature resting }\end{array}$ \\
\hline $\begin{array}{l}\text { South of road, } 14 \mathrm{~km} \text { WSW of } \\
\text { Ruoergai (north end of } \\
\text { Ke Ha Er Qiao) }\end{array}$ & $\begin{array}{l}\text { Vast sedge marsh with } \\
\text { meandering streams }\end{array}$ & $\begin{array}{l}\text { Pair at nest } \\
\text { Pair feeding } \\
\text { Pair feeding } \\
\text { Party of } 3 \text { immatures }\end{array}$ \\
\hline $\begin{array}{l}\text { South of road, } 20-28 \mathrm{~km} \text { WSW } \\
\text { of Ruoergai }\end{array}$ & $\begin{array}{l}\text { Rather dry plain with } \\
\text { some sedge marshes }\end{array}$ & $\begin{array}{l}\text { Pair feeding } \\
\text { One in flight } \\
\text { Party of } 4 \text { immatures }\end{array}$ \\
\hline $\begin{array}{l}\text { South of road, } 28-42 \mathrm{~km} \text { WSW } \\
\text { of Ruoergai }\end{array}$ & $\begin{array}{l}\text { Narrow side valley } \\
\text { with rich peat-bog } \\
\text { and some sedge marsh }\end{array}$ & $\begin{array}{l}\text { Pair at nest } \\
\text { Pair feeding } \\
\text { Pair feeding } \\
\text { Party of } 3 \text { immatures }\end{array}$ \\
\hline $\begin{array}{l}\text { South of road, } 43 \mathrm{~km} \text { WSW of } \\
\text { Ruoergai }\end{array}$ & $\begin{array}{l}\text { Vast marshy plain with } \\
\text { some sedge marshes }\end{array}$ & $\begin{array}{l}\text { Pair feeding } \\
\text { Pair feeding } \\
\text { Pair feeding } \\
\text { Single feeding } \\
\text { Single feeding } \\
\text { Party of } 12 \text { immatures }\end{array}$ \\
\hline $\begin{array}{l}\text { La Nuo Qiao; north of road } \\
35^{-45} \mathrm{~km} \text { west of } \\
\text { Ruoergai }\end{array}$ & $\begin{array}{l}\text { Flooded marsh in broad } \\
\text { valley, with wet peat- } \\
\text { bogs }\end{array}$ & $\begin{array}{l}\text { Pair at nest } \\
\text { Pair at nest } \\
\text { Pair at nest } \\
\text { Pair at nest } \\
\text { Pair at nest } \\
\text { Pair at nest } \\
\text { Pair at nest } \\
\text { Pair feeding } \\
\text { Pair feeding } \\
\text { Pair feeding } \\
\text { Single feeding } \\
\text { Single feeding }\end{array}$ \\
\hline $\begin{array}{l}\text { South of road, } 56-58 \mathrm{~km} \text { WSW } \\
\text { of Ruoergai (near Tangke) }\end{array}$ & $\begin{array}{l}\text { Sedge and peat marshes } \\
\text { on rather dry plain }\end{array}$ & $\begin{array}{l}\text { Single feeding } \\
\text { Single feeding }\end{array}$ \\
\hline $\begin{array}{l}\text { East of road, } 17 \mathrm{~km} \\
\text { south of Tangke }\end{array}$ & $\begin{array}{l}\text { Marshy oxbow lake in } \\
\text { rolling grassland }\end{array}$ & Party of 7 immatures \\
\hline $\begin{array}{l}\text { West of road, } 17-32 \mathrm{~km} \\
\text { north of Ruoergai }\end{array}$ & $\begin{array}{l}\text { Vast marshy plain, } \\
\text { rather dry with old } \\
\text { drainage ditches }\end{array}$ & Pair feeding \\
\hline $\begin{array}{l}\text { West of road, } 36-43 \mathrm{~km} \\
\text { north of Ruoergai }\end{array}$ & $\begin{array}{l}\text { Vast marshy plain; } \\
\text { streams and sedge } \\
\text { marsh through middle, } \\
\text { some small lakes }\end{array}$ & $\begin{array}{l}\text { Pair feeding } \\
\text { Pair feeding } \\
\text { Pair feeding } \\
\text { Pair feeding } \\
\text { Single feeding } \\
\text { Single feeding } \\
\text { Single feeding } \\
\text { Single feeding } \\
\text { Party of } 5 \text { immatures } \\
\text { Party of } 5 \text { immatures }\end{array}$ \\
\hline
\end{tabular}


Table 2 (cont.)

Location
$\begin{aligned} & \text { Plains SSE of Lake Haqiu } \\ & \text { for } 6 \mathrm{~km}\end{aligned}$
Lake Haqiu
Plains between Lake Haqiu
and Cuo Lajan
Cuo Lajan, north of Lake
Haqiu
West of road, $45-50 \mathrm{~km}$
north of Ruoergai

West of road, $54-60 \mathrm{~km}$ north of Ruoergai

Plains $7-9 \mathrm{~km}$ east of Muo Niao Chuo Er Ge

Muo Niao Chuo Er Ge

Plains $\mathrm{I}-6 \mathrm{~km}$ west of Muo Niao Chuo Er Ge

West of road, $26 \mathrm{~km}$ NNE of Xiamen Commune

North-west of road, 11-19 km north-east of Xiamen

East of road, $13 \mathrm{~km}$ ENE of Xiamen Commune

East of road, $11 \mathrm{~km}$ ENE of Xiamen Commune

East of road, $5 \mathrm{~km}$ east of Xiamen Commune

East of road, $9.5 \mathrm{~km}$ east of Xiamen Commune

East of road, $15 \mathrm{~km}$ east of Xiamen Commune
Shallow lake with extensive sedge marshes Marshy plain with sedge marshes along streams

Impounded lake with sedge marsh

Marshy grassland with patches of sedge marsh and some pools

Wet grassland with sedge marshes and small lakes

Small lake with sedge marshes

Shallow lake with sedge marshes

Marshy plain with peatbogs and some sedge marshes

Marshy plain with small lake and marsh

Rather dry plain with some peat-bog

Narrow valley with wet peat-bog

Wet peat-bog between

low hills

Narrow valley with wet peat-bog

Narrow valley with wet peat-bog

Valley with wet peat bog and sedge marsh
Crane observations

Pair at nest

Pair feeding

Pair feeding

Pair feeding

Pair feeding

Single feeding

Pair at nest

Pair at nest

Pair at nest

Pair feeding

Pair resting

Single feeding

Pair feeding

Pair feeding

Pair feeding

Pair feeding

Pair feeding

Pair feeding

Pair feeding

Single feeding

Pair feeding

Pair feeding

Pair feeding

Pair feeding

Pair feeding

Pair feeding

Pair feeding

Pair feeding

Single at nest

Pair at nest

Pair at nest

Pair feeding

Pair feeding

Pair feeding

Pair feeding

Pair feeding

Single feeding

Pair feeding

Pair feeding

Pair at nest

Single feeding

Pair feeding

Single feeding 
Table 2 (cont.)

\begin{tabular}{|c|c|c|}
\hline Location & Habitat & Crane observations \\
\hline $\begin{array}{c}\text { East of road, } 13 \mathrm{~km} \text { ESE } \\
\text { of Xiamen Commune }\end{array}$ & $\begin{array}{l}\text { Narrow valley with wet } \\
\text { peat-bogs }\end{array}$ & Single feeding \\
\hline $\begin{array}{l}\text { East of road, } 8-18 \mathrm{~km} \text { ESE } \\
\text { of Xiamen Commune }\end{array}$ & $\begin{array}{l}\text { Marshy plain with } \\
\text { sedge marshes }\end{array}$ & $\begin{array}{l}\text { Pair at nest } \\
\text { Pair at nest } \\
\text { Single feeding }\end{array}$ \\
\hline $\begin{array}{l}\text { La Lei Qiao, } 26-34 \mathrm{~km} \text { west } \\
\text { of Ruoergai }\end{array}$ & $\begin{array}{l}\text { Wide valley with sedge } \\
\text { marshes, meandering } \\
\text { streams and pools; } \\
\text { peat-bogs in side } \\
\text { valleys }\end{array}$ & $\begin{array}{l}\text { Pair at nest } \\
\text { Pair at nest } \\
\text { Pair feeding } \\
\text { Pair feeding } \\
\text { Pair feeding } \\
\text { Pair feeding } \\
\text { Pair feeding } \\
\text { Pair feeding } \\
\text { Pair feeding } \\
\text { Single feeding } \\
\text { Single feeding } \\
\text { Party of } 3 \text { immatures } \\
\text { Party of } 3 \text { immatures }\end{array}$ \\
\hline \multicolumn{3}{|l|}{ Hongyuan County } \\
\hline $\begin{array}{l}\text { East of road, } 4 \mathrm{~km} \text { south } \\
\text { of Long } \mathrm{Zi} \mathrm{Ba}\end{array}$ & $\begin{array}{l}\text { Wet peat-bog in } \\
\text { side valley }\end{array}$ & Pair feeding \\
\hline $\begin{array}{l}\text { West of road, } 3.5 \mathrm{~km} \text { south } \\
\text { of Wa Chie }\end{array}$ & Wheatfield & Party of 5 immatures \\
\hline $\begin{array}{l}\text { Riganqiao Marsh, 2-30 km } \\
\text { east of Wa Chie }\end{array}$ & $\begin{array}{l}\text { Marshy plain with } \\
\text { streams and sedge } \\
\text { marshes; some } \\
\text { irrigation ditches }\end{array}$ & $\begin{array}{l}\text { Pair at nest } \\
\text { Pair at nest } \\
\text { Pair resting } \\
\text { Pair feeding } \\
\text { Pair feeding } \\
\text { Single feeding } \\
\text { Party of } 6 \text { immatures }\end{array}$ \\
\hline
\end{tabular}

in view of the vast expanses of apparently suitable breeding marsh with few if any cranes.

The presence of 57 first-year birds amongst a total of 240 cranes suggests that Ruoergai Marshes may be of disproportionate importance as a summering area for this age-class. In a sample of 2,845 cranes counted in China and Bhutan during the winter of 1990-1991, 366 were first-winter birds, giving a recruitment rate for the population as a whole of $12.9 \%$ (Bishop 1991). In the same year, the recruitment rate in a total of 759 cranes found wintering in Guizhou and Yunnan (the most likely wintering area for birds from Sichuan) was $15.5 \%$. This is considerably lower than the proportion of first-year birds in the population at Ruoergai Marshes during the summer of 1991 (23.8\%), suggesting that young birds from breeding populations elsewhere on the Tibetan Plateau spend the summer months in these very extensive marshes.

Black-necked Cranes were observed feeding in a variety of marshy habitats as well as on the adjacent dry grasslands and, on one occasion, five first-year birds were found feeding in a large wheatfield near the village of Wa Chie. However, all 24 nests were located in very wet marshes, mostly inaccessible to domestic livestock. Over half of the nests (13 sites) were situated in the middle 
of large wet sedge marshes in broad valleys. Six nests were located in wet sedge marshes in the "deltas" of small streams where they emerged from side valleys onto the plains, while a further four were situated in sedge marshes at the edge of small lakes. Only one nest was located in the midst of a hummocky peat-bog, although this habitat was often used by feeding birds. No attempt was made to study the nesting behaviour of the cranes, and none of the nests was visited on foot or disturbed in any way.

The total count of 216 Black-necked Cranes in Ruoergai County must represent only a small proportion of the cranes present in the area at the time. An attempt has been made to estimate the extent of coverage achieved by the expedition on the basis of the extent of suitable crane habitat indicated on the 1:100,000 topographical maps and the actual area surveyed. Using a system of $2 \times 2 \mathrm{~km}$ grid squares, it was estimated that there were some 269,300 ha of marshes in Ruoergai County, distributed in 1,202 grid squares. The expedition was able to cover approximately 78,350 ha of marsh in 382 grid squares, i.e. $29.1 \%$ of the total area. Direct extrapolation yields a total of 740 cranes. As many as 24 birds may have been overlooked in the area thought to have been covered, namely the mates of the 23 single feeding birds and the mate of single bird at a nest. If these hypothetical birds are taken into account, the extrapolated total becomes 825 .

These estimated totals are likely to be too high because of the bias in the survey towards sites which appeared from the maps to be the most suitable for cranes. However, large areas of what appeared to be excellent crane habitat could not be visited because of its remoteness and the shortage of time. In particular, there are huge areas indicated as deep marsh between Lake Haqiu and the Heihe River in the north, and between the Tangke-Ruoergai road and the Hongyuan County boundary in the south. The latter marsh (Ke Ha Er Qiao) is particularly extensive, covering some 20,000 ha. Nine cranes were observed from a single vantage point at the extreme northern end of this marsh, but no coverage was possible of the remainder of the marsh which stretched away for some $23 \mathrm{~km}$ to the county boundary and beyond.

Taking these uncertainties into account, it was concluded that the total number of Black-necked Cranes in the marshes of Ruoergai County in May and June 1991 was probably between 500 and 700 . To these can be added some 50 to 100 cranes in the contiguous marshes of northern Hongyuan County, and perhaps a similar number in the extensive marshes to the west of the Baihe River in neighbouring Gansu Province (Maqu County). An unknown but probably much smaller number of cranes occur in the isolated peat-bogs and marshes further south in Hongyuan County. Taken together, these figures suggest that the total population of Black-necked Cranes on the Hongyuan-Ruoergai Plateau in 1991 was between 600 and 900 birds. Of these, perhaps 280 to 400 were breeding adults (representing 140 to 200 breeding pairs), with the remainder comprising first-year birds ( 120 to 200 ) and subadults (200 to 300 ). 


\section{Conservation of the Black-necked Cranes and their wetland habitats}

\section{Management problems}

Potential threats to the Black-necked Cranes and their wetland habitats include peat-mining, overgrazing and wetland drainage. Direct persecution does not appear to pose a significant threat to the cranes or other wildlife at the present time. By tradition, the local tribespeople eat "neither fish nor fowl", and indeed hunting is contrary to their religious beliefs. As a consequence, wildlife is seldom molested. This was apparent from the unusual tameness not only of the Black-necked Cranes, which were commonly seen feeding in close proximity to nomad encampments and were occasionally seen within a few metres of main roads, but also of ducks, geese and other wildlife. Tibetan gazelles were seen on several occasions grazing in close proximity to nomads and their flocks, and even wolves seemed relatively unafraid of man. There is some hunting by resident and visiting ethnic Chinese, and this could increase as domestic tourism to the region increases, but the local authorities in Ruoergai knew of no instances of cranes being killed. On the other hand, the local people do collect birds' eggs for consumption, although these were reported to be mostly of smaller birds such as Redshank and Common Tern.

The expedition spent some time investigating reports that the commercial exploitation of peat for energy production had resulted in the loss of important wetland habitat and was posing a threat to the crane population. The exploitation of peat for energy production in the Hongyuan-Ruoergai Plateau has been documented by Bjork and Digerfeldt (1990). It has been estimated that there are some 400,000 ha of peatlands on the Hongyuan-Ruoergai Plateau, containing about 1.9 billion metric tonnes of air-dried peat. This constitutes the largest area of peatland in China, and one of the largest in the world. The peat occurs in two types of deposit: soligenous mires on hill slopes, dependent mainly on surface-water runoff; and topogenous mires in large depressions between hills, dependent mainly on ground water. Preliminary investigations suggest that a major proportion of the peat has a very high ash content and is unsuitable or only marginally suitable for energy production. The best quality peats occur in the soligenous deposits in the hilly areas in the south.

It soon became apparent during the present survey that peat-mining activities were not as yet posing any threat to the principal crane breeding marshes. There had been no mining of peat in the main marshes in Ruoergai County, where the peat deposits are of poor quality for energy production, and there were no plans for mining in the future. Peat extraction was confined to a small area around the town of Hongyuan, some $90 \mathrm{~km}$ south-south-west of Ruoergai and $40 \mathrm{~km}$ from the nearest crane breeding areas. A Sino-Swedish Peat Mining Project has been set up in the Hongyuan area, but this is a small-scale endeavour producing peat exclusively for local use, principally in the milk-powder and brick factories in Hongyuan, and there are no plans to produce peat on a large scale for export to other parts of China. The Sino-Swedish project has given considerable attention to environmental concerns, and is promoting the use of an extraction technique which allows for rapid restoration of mined areas to pastureland with minimum ecological damage (Bjork and Digerfeldt 1990). 
On the other hand, overgrazing is widely acknowledged to be a serious problem throughout the grasslands, and was apparent from the generally poor condition of the livestock and large numbers of corpses observed during the present survey. However, there seems little that the authorities can do to control livestock numbers. As an ethnic minority, the local tribespeople have a considerable degree of autonomy, and the authorities from central government are understandably reluctant to impose any unpopular restrictions such as controls on livestock numbers. Although the overgrazing is creating a number of problems for the livestock industry, it is doubtful if it is having any serious detrimental effects on the main marshes or their wildlife. Many of the marshes are too wet to support domestic livestock other than horses, while even in the drier peripheral areas much frequented by yak and sheep, the abundance of marmots, gazelles and ground-nesting birds suggests that the situation is not yet critical for wildlife.

The principal long-term threat to the wetlands and Black-necked Cranes of the Hongyuan-Ruoergai Plateau is drainage of the peat-bogs and sedge marshes for pastureland. Many of the marshy valleys and hillside bogs in Hongyuan county have already been drained, and are now no longer suitable for breeding cranes. Every marsh and bog along the Wa Chie to Songpan road at the southern edge of the main marshes showed signs of drainage in June 1991. In most cases, the drainage took the form of longitudinal ditches, hand-dug through soligenous peat-bogs on gently sloping hillsides, but there was a considerable network of ditches on the marshy plain near Wa Chie, an important site for Black-necked Cranes. All of the peat-bogs were being heavily grazed by domestic livestock; the surfaces were badly trodden, and gully erosion was occurring in many places.

By contrast, there was little evidence of wetland drainage in the main marshes in Ruoergai County, probably because drainage of these deep topogenous mires is much more complicated and requires much greater investment. Attempts were made in the 1950s and again in the 1970s to drain parts of the eastern edge of the marshes north of Ruoergai town, but these efforts proved to be expensive and largely unsuccessful. Some of the old drainage ditches were still visible in 1991, but many of these had become blocked and were ineffective. The county authorities confirmed in June 1991 that there were no plans for large-scale drainage of the marshes in the foreseeable future because of the lack of technology and financial resources.

However, the problem of overgrazing and the pressure to drain marshes for pastureland will continue to increase as the numbers of livestock increase. Bjork and Digerfeldt (1990) report a 3.5 -fold increase in the number of yak in the Hongyuan region between 1960 and 1989 , and a $1-2 \%$ annual increase in livestock numbers in that county in recent years. Although there may be no immediate plans to drain large areas of marsh, the stated policy for solving the overgrazing problem is to increase the area of grassland and improve the quality of the grazing, rather than to control the numbers of livestock. The only conceivable way to increase the area of grassland would be to drain the wetlands probably a relatively straightforward task given access to modern technology and the necessary financial resources.

The success of wetland conservation in the Hongyuan-Ruoergai Plateau and 
the long-term survival of the Black-necked Cranes will therefore be dependent on the establishment of some form of reserve or management area in which wetland drainage is prohibited or strictly controlled. While the establishment of such a protected area may not be fully effective in preventing the local people from attempting some drainage of wetlands on a small scale, it should deter provincial, national and international agencies from supporting any major drainage schemes in the key areas.

\section{Establishment of a crane reserve}

In 1985, the Sichuan Forestry Department and Sichuan Institute of Natural Resources put forward a proposal to establish a nature reserve of 87,000 ha in the Xiamen region to protect the cranes and their wetland habitat. However, no progress was made with this proposal, partly because of financial constraints, and partly because of considerable opposition from the local people who feared that restrictions would be placed on their traditional nomadic lifestyle. The present expedition spent some time discussing the problems of reserve establishment with the Sichuan Forestry Department, government officials in Ruoergai County and the local people. It was apparent that any large nature reserve which severely restricted the freedom of the tribespeople to graze their livestock in the grasslands and marshes would be doomed to failure. While it might be feasible to establish one or two small nature reserves in key areas of marsh, these would protect so few pairs of cranes as to be ineffective in protecting the crane population as a whole. It became clear that an alternative solution to wetland and crane conservation in the area would have to be found.

It was finally agreed that the best solution would be to establish a large special protection zone for the cranes (Crane Conservation Area) in which the emphasis would be on maintaining the status quo. No restrictions would be imposed on the traditional pastoral activities of the local tribespeople, but wetland drainage, peat-mining and any other development activities likely to bring about a change in the ecological character of the wetlands would be prohibited. The Tibetan religion protects the cranes and other wildlife from persecution by the tribespeople, while the existing local county laws forbidding hunting could be used to control hunting by visitors from other parts of China. Some special wardening of the main crane breeding areas would be desirable during the actual nesting period to minimize disturbance in the immediate vicinity of nests.

Preliminary discussions with the Ruoergai County authorities and Sichuan Forestry Department indicated that the establishment of such a Crane Conservation Area would find wide acceptance. Provisional boundaries were drawn up, encompassing about 247,000 ha of plains and hill ranges in Ruoergai County, and including about 152,000 ha of wetlands (see Figure 1). These wetlands held $192(80 \%)$ of the Black-necked Cranes observed during the survey, and 19 of the 24 nests.

WWF is now discussing this proposal with officials in the Sichuan Forestry Department, and examining ways in which it can support the establishment of a protected area for the Black-necked Cranes. 


\section{Discussion}

The Black-necked Crane is one of the world's rarest cranes. The great majority breed in bogs and marshes on the Tibetan Plateau in China, although there are a few breeding pairs in Ladakh in India. The cranes undertake relatively short migrations to spend the winter in marshy meadows at slightly lower elevations in south-west China, Bhutan and (at least formerly) north-east India and Vietnam. As recently as 1988, the world population was thought to number no more than about 1,400 to 1,500 birds (Collar and Andrew 1988). Since the winter of 1988-1989, ICF has coordinated annual censuses of Black-necked Cranes on their winter quarters. These censuses have greatly improved our knowledge of the numbers of the species and revealed that the world population is considerably larger than was formerly supposed. A total of 5,554 Black-necked Cranes was recorded during the census of 1991-1992, with 315 in Bhutan and the remainder in China (Bishop 1992). New wintering areas continue to be discovered, and it seems possible that the total population could be as high as 6,000 birds.

The present survey has shown that the marshes of the Hongyuan-Ruoergai Plateau are an extremely important summering area for Black-necked Cranes, probably holding between 600 and 900 cranes and hence some $10-15 \%$ of the world population during the summer months. The breeding population is estimated at between 140 and 200 pairs, making this the most important breeding area for Black-necked Cranes hitherto discovered. In addition, the marshes appear to be an important summering area for immature birds from other breeding areas, and may therefore play a vital role in maintaining recruitment into breeding populations over a wide area of the Tibetan Plateau.

Every effort should now be made to establish some form of protected area in the Ruoergai Marshes to maintain the ecological character of the wetlands and safeguard the habitat for the cranes. There is an urgent need for more detailed studies of the Black-necked Cranes, specifically to provide baseline data for regular monitoring, to determine breeding success and the possible impact of disturbance, and to identify the migration routes and wintering areas of the cranes through a colour-banding programme. At the same time, there is an urgent need to tackle the problem of overgrazing throughout the grasslands of Ruoergai and Hongyuan counties. Solutions should be sought through improved range management and the control of livestock numbers, rather than through large-scale drainage of wetlands to increase the area of pastureland.

\section{Acknowledgements}

I wish to express my gratitude to the World Wide Fund for Nature for providing the financial support for this survey and to WWF-Hong Kong for making all the arrangements for my visit to China. I would like to thank the Sichuan Forestry Department for providing logistic support for the fieldwork, and the Ruoergai Forestry Bureau, Hongyuan Forestry Bureau and Ruoergai County Authorities for their invaluable help and advice in the field. In particular, I would like to thank my companions on the survey, Mr Wang Shun Yang and $\mathrm{Mr}$ Yang $\mathrm{Xu} \mathrm{Yi}$ from the Division for Conservation and Management of Wild 
Fauna and Flora in the Sichuan Forestry Department, and our driver Mr Yang Bin for their hard work and good humour throughout.

\section{References}

Anon. (1990) North-west Sichuan peat mining likely to threaten rare waterbirds. Asian Wetland News 2(2): 6.

Archibald, G. and Oesting, M. (1981) Black-necked Crane: a review. Pp. 190-196 in J. C. Lewis and $\mathrm{H}$. Masatomi, eds. Crane research around the world. Baraboo, Wisconsin: International Crane Foundation.

Bishop, M. A. (1991) Results of the third Black-necked Crane winter count in Bhutan and China. Baraboo, Wisconsin: International Crane Foundation, unpublished report.

Bishop, M. A. (1992) Results of the Black-necked Crane 1991-1992 winter count in Bhutan, China, and India. Baraboo, Wisconsin: International Crane Foundation, unpublished report.

Bjork, S. and Digerfeldt, G. (1990) Environmental compatibility planning prior to the exploitation of peat-rich areas - a holistic approach to a region in Sichuan Province, China. Paper presented at a Plenary Conference to mark the 2oth Anniversary of the Gesellschaft für Oekologie, Freising-Weihenstephan, 15-22 September 1990.

Collar, N. J. and Andrew, P. (1988) Birds to watch: the ICBP world checklist of threatened birds. Cambridge, U.K.: International Council for Bird Preservation (Techn. Publ. 8).

Johnsgard, P. A. (1983) Cranes of the world. London and Canberra: Croom Helm.

Scott, D. A. (1989) A directory of Asian wetlands. Cambridge, U.K. and Gland, Switzerland: International Union for Conservation of Nature and Natural Resources.

Scott, D. A. (1991) Survey of Ruoergai Marshes and Xiamen Proposed Nature Reserve, Sichuan, China: 22 May-19 June 1991. WWF, Switzerland: Report of WWF Project: 4002.06/China.

DEREK A. SCOTT

Runagate, Far Green, Coaley, Dursley, Glos. GL11 5EL, U.K. 